\title{
Correct positioning of double-lumen tubes
}

\author{
Jean S. Bussières, MD · Peter Slinger, MD
}

Received: 5 January 2012/ Accepted: 17 February 2012/Published online: 7 March 2012

(c) Canadian Anesthesiologists' Society 2012

Today it is your turn in the thoracic operating room, and your patient is scheduled for a right video-assisted thoracoscopic surgery (VATS). You know about the benefits of protective lung ventilation, a strategy that involves small tidal volumes and modest plateau pressures during onelung ventilation $(\mathrm{OLV}) .{ }^{1}$ You have no problem inserting a left-sided double-lumen tube (DLT), and you check its position with fibreoptic bronchoscopy (FOB). After turning your patient to the left lateral decubitus position, you institute OLV with the following parameters: tidal volume: $6 \mathrm{~mL} \cdot \mathrm{kg}^{-1}$; respiratory rate: 15 breaths $\cdot \mathrm{min}^{-1}$; initial inspired oxygen fraction: 0.80; and positive endexpiratory pressure (PEEP) $5 \mathrm{cmH}_{2} \mathrm{O}$. You are happy now because you managed OLV using the best technique you know.

A few minutes after the start of surgery, the spirometer shows a defect in the expiratory loop, indicating a leak. ${ }^{2} \mathrm{~A}$ few seconds later, the oxygen saturation levels decrease to the low 90s. Moreover, the surgeon mentions to you that the right lung is inflating; consequently, it is impossible to proceed with the VATS. The conditions are deteriorating from bad to worse. A beautiful day is turning so easily into a bad one! How could you have avoided this situation?

Since the introduction of modern disposable polyvinyl chloride DLTs at the beginning of the 1980s and the

\section{J. S. Bussières, MD ( $₫)$}

Département d'anesthésiologie, Institut universitaire de cardiologie et de pneumologie de Québec,

2725, Chemin Sainte-Foy, Ville de Québec,

QC G1V 4G5, Canada

e-mail: jbuss@criucpq.ulaval.ca

\section{P. Slinger, MD}

Department of Anesthesia, Toronto General Hospital,

Toronto, ON, Canada routine use of FOB, anesthesiologists have increased their expertise in positioning DLTs. Their thorough knowledge of tracheobronchial anatomy and refinements in DLT positioning techniques has produced excellent results. Correct FOB positioning of DLTs is probably the main factor responsible for reducing the incidence of desaturation during OLV and increasing the safety of OLV. Correct positioning of the DLT prior to surgery decreases the number of repositionings required during surgery.

\section{Cervical spine movement}

In this issue of the Journal, Seo et al. ${ }^{3}$ describe the results of an interesting investigation that caught our interest. Every anesthesiologist using DLTs will probably find the conclusions of the study relevant to her/his practice. The authors compared the position of left-sided DLTs (L-DLTs) before and after turning patients to the lateral decubitus position for thoracic surgery, as assessed by FOB. The DLT was fixed with the patients in the supine position, with their head positioned either on a headrest or flat on the table. The authors found more DLT movement in patients whose DLT was positioned with a headrest than in those whose DLT was positioned without a headrest.

This study is a modern and more clinically relevant version of an older study published in 1985. At that time, Saito and Naito ${ }^{4}$ presented the results of a study involving tracheal intubation with a L-DLT with the patients in the supine position. The authors induced flexion and extension of the cervical spine and measured DLT displacement radiologically. They reported that flexion of the neck caused a distal (inward) migration of the L-DLT and extension of the neck caused a proximal (outward) 
displacement. The distal tip of the L-DLT moved a mean of $27 \mathrm{~mm}$ (standard deviation 6; range $15-35 \mathrm{~mm}$ ). The authors warned readers against potential complications: Flexion may produce left upper lobe bronchus obstruction, and extension may provoke bronchial cuff herniation above the carina.

Seo et al. performed a more clinically relevant study. The only movement they applied to the cervical spine was that associated with the usual mobilization of the patient during turning to the lateral surgical position. Consequently, their DLTs moved less than those in Saito and Naito's study. ${ }^{4}$ When the patient's neck was first flexed on a headrest, mean displacement was usually outward, with a mean value of $11.6 \mathrm{~mm}$ (range -5 to $21 \mathrm{~mm}$ ); however, when the patients first lay supine without a headrest, there was less displacement of the distal tip of the L-DLT, with a mean value of $6.0 \mathrm{~mm}$ (range -5 to $12 \mathrm{~mm})(P<0.001)$. Their results also showed that all significant displacements $(>10 \mathrm{~mm}$ ) were outward in direction and more frequent (64\% vs 28\%) in the group with a headrest during initial FOB positioning of the DLT.

\section{New landmarks in positioning L-DLTs}

There is another point to consider when positioning a L-DLT. In their protocol, Dr. Seo et al. used the BronchoCath L-DLT (Mallinckrodt Inc, St-Louis, MO, USA), and they established their end point as "the bronchial cuff was placed just below the carina without herniation". One of the authors of this article (J.B.) ${ }^{5}$ proposed an alternative landmark to position the Broncho-Cath L-DLT. The design of the Broncho-Cath was modified in 1994 to include a black radiopaque line located proximal to the bronchial cuff. We proposed a deeper optimal position of the L-DLT, i.e., to align the carina between the black radiopaque line and the superior portion of the bronchial cuff (Figure A). This was accomplished by FOB visualization of the tracheal carina through the transparent wall of the bronchial lumen. In 2001, we compared the incidence of clinically significant outward displacement in two groups of patients. In one group, the DLT was positioned with the bronchial cuff just below the carina; in the other group, the deeper position was adopted by aligning the carina between the radiopaque line and the bronchial cuff. The results showed a significant decrease in clinically important outward displacement with the deeper position compared with the classic technique used by Dr. Seo et al. (16\% vs 43\%, respectively). The deeper position described here adds a safety margin that may be as high as $10 \mathrm{~mm}$ when the black radiopaque line is aligned with the tracheal carina (Figure A). This minimizes the clinical effects of outward displacement (bronchial cuff herniation) frequently associated with patient lateral positioning. Unfortunately, some commercial designs of L-DLTs have characteristics (e.g., an opaque bronchial lumen wall) precluding their use for this technique. ${ }^{6}$

\section{Anatomy}

Anesthesiologists' lack of familiarity with FOB tracheobronchial anatomy is one of the major causes of DLT malposition. ${ }^{7}$ There are two major FOB end points when positioning L-DLTs. First, it is essential to obtain an unobstructed view of the left upper and left lower bronchial orifices (Figure B). This position is most important to institute safe OLV. The second end point is correct placement of the bronchial cuff below the carina (Figure A). This end point is secondary relative to the first one, as the bronchial cuff position should be tailored to the first end point to achieve an airtight seal.

The margin of safety is small when positioning L-DLTs $(16-19 \mathrm{~mm})$, and it is even less when positioning rightDLTs $(1-4 \mathrm{~mm}){ }^{8}$ For several reasons, the DLT moves relative to the tracheobronchial tree when the patient is turned to the lateral position. First, the carina probably shifts when the patient is moved from the supine to the lateral chest-open position. ${ }^{9}$ Second, most anesthesiologists intubate the trachea with the patient's cervical spine in some version of the "sniffing" position (cervical spine flexion and head extension) ${ }^{10}$; however, the cervical spine is then re-positioned in the neutral position after the patient is turned for surgery.

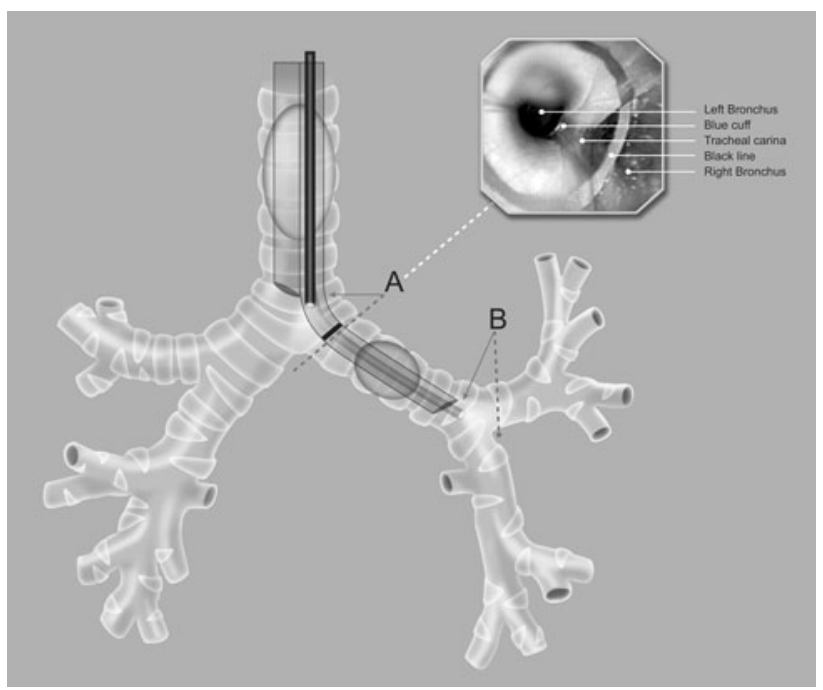

Figure Positioning of the left-double lumen tube (DLT) with fibreoptic bronchoscopy (FOB). Position A: Visualization of the tracheal carina by FOB through the transparent wall of the DLT bronchial lumen. Position B: The unobstructed view of the left upper and left lower bronchial orifices 


\section{Check and recheck}

It is important to check DLT placement initially with the patient in the supine position after tracheal intubation and to reposition the DLT correctly as needed at that time. If the DLT is seriously malpositioned (e.g., a left-sided DLT in the right mainstem bronchus), it is more difficult to reposition the DLT after turning the patient to the lateral position. This adjustment of the DLT position is best performed with FOB. Before FOB was available, verification was done with auscultation and alternate occlusion of the DLT lumens to guide placement. Auscultation is still an option if FOB is not available; however, there is a high incidence of undetected malpositioning when auscultation is used alone. ${ }^{11}$ One of the authors (P.S.) uses a combination of auscultation first and then FOB during the initial DLT positioning. If the DLT seems to be placed in the correct mainstem bronchus on auscultation, the initial FOB is performed via the tracheal lumen of the DLT. This technique is used because it is easier to get a wide field of view and to orient oneself with FOB from the tracheal lumen in a correctly positioned DLT. The fibreoptic bronchoscope is then passed down the bronchial lumen to fine-tune the DLT position and to avoid lobar obstruction, which is very difficult to detect with auscultation. However, if on initial auscultation the DLT seems to be in the contralateral (incorrect) bronchus, the bronchoscope is passed initially down the bronchial lumen so that the DLT can easily be withdrawn above the carina under direct vision and then advanced down the correct mainstem bronchus. This protocol can save time and frustration as it can be very disorienting if the bronchoscope is passed initially down the tracheal lumen of a DLT which has been placed unknowingly into the incorrect mainstem bronchus (e.g., a left-DLT in the right mainstem bronchus). After turning the patient, a recheck of the DLT position must then be performed with the fibreoptic bronchoscope.

\section{Conclusions}

To avoid frustration during the surgical procedure, as described at the beginning of this editorial, the DLT should be positioned meticulously. This can be accomplished in more than one way, but it is the small details taken together that will bring success to this field. These details include: knowledge of tracheobronchial anatomy; deeper insertion of the L-DLT in the left mainstem bronchus (as long as the left lobar carina is clear); and finally, minimizing cervical spine movement while attempting to maintain the spine in the neutral position.

\section{Positionnement correct des tubes à double lumière}

Aujourd'hui, c'est votre tour de travailler dans la salle de chirurgie thoracique et votre patient doit subir une chirurgie thoracique vidéo-assistée (VATS) du côté droit. Vous connaissez les avantages de la ventilation pulmonaire protectrice, une stratégie qui implique de petits volumes courants et des pressions de plateau modestes au cours de la ventilation unilatérale $(\mathrm{OLV}) .{ }^{1}$ Vous n'avez pas de difficulté à insérer un tube à double lumière (DLT) gauche et vous vérifiez sa position en effectuant une bronchoscopie à fibres optiques. Après avoir tourné votre patient en décubitus latéral gauche, vous commencez la ventilation unilatérale avec les paramètres suivants: volume courant: $6 \mathrm{~mL} \cdot \mathrm{kg}^{-1}$; fréquence respiratoire: de 15 respirations. $\min ^{-1}$; fraction initiale d'oxygène inspiré: 0.80 ; et pression positive télé-expiratoire (PEEP) de $5 \mathrm{cmH}_{2} \mathrm{O}$. Vous êtes maintenant satisfait parce que vous gérez l'OLV en utilisant la meilleure technique que vous connaissez.

Quelques minutes après le début de l'intervention, le spiromètre indique une boucle non fermée, témoin d'une fuite. $^{2}$ Quelques secondes plus tard, la saturation en oxygène diminue aux alentours de $90 \%$. De plus, le chirurgien vous signale que le poumon droit se gonfle; il est par conséquent impossible de poursuivre la VATS. La situation se détériore et va de mal en pis. Une belle journée se change si facilement en mauvais jour! Comment auriez-vous pu éviter une telle situation?

Depuis l'introduction des DLT modernes jetables en polychlorure de vinyle au début des années 1980 et l'utilisation courante de la bronchoscopie à fibres optiques, les anesthésiologistes ont acquis une meilleure expertise dans la mise en place des DLT. Leur connaissance approfondie de l'anatomie de l'arbre trachéobronchique et les perfectionnements de la technique de positionnement des DLT a produit d'excellents résultats. Le positionnement correct des DLT sous contrôle fibroscopique est probablement le principal facteur ayant permis de réduire l'incidence des épisodes de désaturation au cours de l'OLV et d'augmenter l'innocuité de cette dernière. Le positionnement correct du DLT avant l'intervention chirurgicale réduit le nombre de repositionnements nécessaire au cours de la chirurgie.

\section{Mouvement de la colonne cervicale}

Dans ce numéro du Journal, Seo et coll. ${ }^{3}$ décrivent les résultats intéressants d'une recherche qui a capté notre attention. Chaque anesthésiologiste utilisant des DLT trouvera sans doute les conclusions de l'étude pertinentes pour sa pratique. L'auteur a comparé la position - évaluée 
par bronchoscopie à fibres optiques - des DLT du côté gauche (DLT-g) avant et après avoir tourné les patients en décubitus latéral pour une chirurgie thoracique. Le DLT était fixé alors que les patients étaient en décubitus dorsal, leur tête étant posée sur un appuie-tête ou à plat sur la table. Les auteurs ont observé davantage de mouvements des DLT chez les patients lorsque le DLT avait été placé avec un appuie-tête que lorsque les patients reposaient à plat au moment de la mise en place.

Cette étude est une version moderne et cliniquement plus pertinente d'une étude plus ancienne publiée en 1985. Saito et Naito ${ }^{4}$ avaient alors publié les résultats d'une étude sur l'intubation trachéale avec un DLT-g chez des patients en décubitus dorsal. Les auteurs avaient provoqué une flexion et une extension de la colonne cervicale et mesuré radiologiquement le déplacement du DLT. Selon leur article, la flexion du cou entraînait une migration distale (vers l'intérieur) du DLT gauche, tandis que l'extension du cou entraînait un déplacement proximal (vers l'extérieur). L'extrémité distale du DLT-g s'était déplacée en moyenne de $27 \mathrm{~mm}$ (écart-type: $6 \mathrm{~mm}$; extrêmes: 15-35 mm). Les auteurs avaient mis en garde leurs lecteurs contre des complications éventuelles: la flexion peut provoquer une obstruction de la bronche lobaire supérieure gauche et l'extension peut provoquer une hernie du ballonnet bronchique au-dessus de la carène.

Seo et coll. ont réalisé une étude plus pertinente d'un point de vue clinique. Ils n'ont soumis la colonne vertébrale qu'à un seul mouvement: celui qui est associé à la mobilisation habituelle du patient lorsqu'il est tourné sur le côté en position chirurgicale. En conséquence, leurs DLT ont moins bougé que ceux de l'étude de Saito et Naito. ${ }^{4}$ Quand le cou du patient était fléchi initialement sur l'appuie-tête, le déplacement moyen s'est habituellement fait vers l'extérieur, et avait une valeur moyenne de 11,6 mm (extrêmes: -5 à $21 \mathrm{~mm}$ ); toutefois, quand les patients étaient allongés initialement en décubitus dorsal sans appuie-tête, le déplacement de l'extrémité distale du DLT gauche était moindre, avec une valeur moyenne de $6,0 \mathrm{~mm}$ (extrêmes: -5 à $12 \mathrm{~mm}) \quad(P<0,001)$. Leur résultats ont également montré que tous les déplacements significatifs $(>10 \mathrm{~mm}$ ) se faisaient vers l'extérieur et plus souvent (64\% contre $28 \%$ ) dans le groupe ayant bénéficié d'un appuie-tête au cours du positionnement du DLT par bronchoscopie.

\section{Nouveaux points de repère pour le positionnement des DLT gauches}

Il y a un autre élément à prendre en compte lors du positionnement d'un DLT-g. Dans leur protocole, Seo et coll. ont utilisé le DLT-g Broncho-Cath (Mallinckrodt Inc,
St-Louis, Missouri, États-Unis) et ils ont déterminé leur critère d'évaluation ainsi: «le ballonnet bronchique était placé juste en dessous de la carène sans faire de hernie ». L'un de nous (J.B.) ${ }^{5}$ a proposé un autre point de repère pour positionner le DLT-g Broncho-Cath. Le design du Broncho-Cath a été modifié en 1994 et inclut maintenant une ligne noire radio-opaque située en position proximale par rapport au ballonnet bronchique. Nous avons proposé une position optimale plus profonde du DLT-g, de façon à ce que la carène soit entre la ligne noire radio-opaque et la partie supérieure du ballonnet bronchique (Figure A). Ce positionnement s'effectue par visualisation au bronchoscope de la carène trachéale au travers de la paroi transparente de la lumière bronchique. En 2001, nous avons comparé l'incidence des déplacements cliniquement significatifs vers l'extérieur dans deux groupes de patients. Dans un groupe, le DLT était positionné de façon à ce que le ballonnet bronchique se trouve juste en dessous de la carène; dans l'autre groupe, une position plus profonde était adoptée en alignant la carène entre la ligne radio-opaque et le ballonnet bronchique. Les résultats ont montré une diminution significative des déplacements cliniquement importants vers l'extérieur avec la position la plus profonde par rapport à la technique utilisée par Seo et coll. (respectivement, $16 \%$ contre $43 \%$ ). La position plus profonde décrite ici ajoute une marge de sécurité qui peut atteindre $10 \mathrm{~mm}$ lorsque la ligne noire radio-opaque est alignée avec la carène trachéale (Figure $\mathrm{A}$ ). Ce positionnement minimise les conséquences cliniques d'un déplacement vers l'extérieur (hernie du ballonnet bronchique) fréquemment associé à la mise en position latérale du patient. Malheureusement, les caractéristiques du design de certains DLT-g commercialisés (comme une paroi de lumière bronchique opaque) ne permettent pas de les utiliser pour cette technique. $^{6}$

\section{Anatomie}

Le manque d'expérience des anesthésiologistes avec l'anatomie trachéobronchique en bronchoscopie est l'une des principales causes de mauvais positionnement des DLT. $^{7}$ Il y a deux critères d'évaluation principaux du positionnement des DLT-g par bronchoscopie. Tout d'abord, il est essentiel d'avoir une vue totalement dégagée des orifices des bronches lobaires supérieure et inférieure gauches (Figure B). Cette position est la plus importante pour mettre en place une OLV sans danger. Le second critère d'évaluation est le placement correct du ballonnet bronchique en dessous de la carène (Figure $\mathrm{A}$ ). Ce critère est secondaire par rapport au premier, car la position $\mathrm{du}$ ballonnet bronchique doit être choisie en fonction du premier pour obtenir une étanchéité à l'air. 
La marge de sécurité est faible pour le positionnement des DLT-g (16 à $19 \mathrm{~mm})$ et elle est encore plus faible pour le positionnement des DLT-droits $(1$ à $4 \mathrm{~mm}) .{ }^{8}$ Le DLT se déplace par rapport à l'arbre trachéobronchique pour plusieurs raisons quand le patient est tourné en décubitus latéral. Premièrement, il est probable que la carène bouge lorsque le patient est déplacé du décubitus dorsal en position latérale à thorax ouvert. ${ }^{9}$ Deuxièmement, la plupart des anesthésiologistes intubent la trachée en plaçant la colonne cervicale des patients dans une sorte de position de « reniflage » (colonne cervicale en flexion et tête en extension) $;{ }^{10}$ toutefois, la colonne cervicale est ensuite repositionnée en position neutre après avoir tourné le patient pour l'intervention.

\section{Vérifier et revérifier}

Il est important de vérifier la position initiale du DLT lorsque le patient est en décubitus dorsal après intubation trachéale et de repositionner correctement le DLT si nécessaire à ce moment-là. Si le DLT est nettement mal positionné (par exemple, un DLT gauche dans la bronche souche droite), il est plus difficile de le repositionner après avoir tourné le patient en décubitus latéral. Cet ajustement de la position du DLT s'effectue de préférence à l'aide de la bronchoscopie. Avant l'époque des fibroscopes, la vérification ne pouvait être faite que par auscultation et occlusion alternée des lumières du DLT pour guider le placement. L'auscultation est toujours disponible s'il n'y a pas de bronchoscope disponible. Néanmoins, l'incidence des mauvais positionnements non détectés par l'auscultation utilisée seule est élevée. ${ }^{11}$ L'un de nous (P.S.) utilise une combinaison des deux techniques au cours du positionnement initial du DLT: d'abord l'auscultation puis la bronchoscopie. $\mathrm{Si}$, à l'auscultation, le DLT semble être placé dans la bonne bronche souche, on introduit le bronchoscope d'abord dans la lumière trachéale du DLT. Cette technique est utilisée parce qu'il est plus facile d'avoir un grand champ de vision et de s'orienter avec un bronchoscope à partir de la lumière trachéale dans un DLT correctement positionné. Le bronchoscope est alors passé dans la lumière bronchique pour régler finement la position du DLT et éviter une obstruction lobaire qui est très difficile à détecter à l'auscultation. Si à l'auscultation initiale, le DLT semble être positionné dans la bronche controlatérale (incorrecte) le bronchoscope est descendu dans la lumière bronchique de façon à ce que le DLT puisse être facilement retiré au-dessus de la carène sous vision directe puis redescendu dans la bonne bronche souche. Ce protocole peut faire gagner du temps et éviter des frustrations car on peut être désorienté si le bronchoscope est passé d'abord dans la lumière bronchique d'un DLT qui a été placé, sans le savoir, dans la mauvaise bronche souche (par exemple, un DLT gauche placé dans la bronche souche droite). La position du DLT doit être revérifiée par bronchoscopie après avoir tourné le patient.

\section{Conclusions}

Pour éviter des frustrations au cours de l'intervention chirurgicale, comme décrit au début de cet éditorial, le DLT doit être positionné de façon méticuleuse. Il y a plus d'une façon d'y parvenir, mais ce sont les petits détails qui mis bout à bout permettront de réussir ce geste. Ces détails incluent: la connaissance de l'anatomie trachéobronchique; une insertion plus profonde du DLT-g dans la bronche souche gauche (pour autant que la carène de la bronche lobaire gauche soit dégagée); et, enfin, réduire le mouvement de la colonne cervicale tout en essayant de la maintenir en position neutre.

Funding No source of funding.

Conflicts interest None declared.

\section{References}

1. Lohser J. Evidence-based management of one-lung ventilation. Anesthesiol Clin 2008; 26: 241-72.

2. Bardoczky GI, Levarlet M, Engelman E, deFrancquen P. Continuous spirometry for detection of double-lumen endobronchial tube displacement. Br J Anaesth 1993; 70: 499-502.

3. Seo JH, Hong DM, Lee JM, Chung EJ, Bahk JH. Double-lumen tube placement with the patient in the supine position without a headrest minimizes displacement during lateral positioning. Can J Anesth 2012; 59: this issue. DOI:10.1007/s12630-012-9679-7.

4. Saito $S$, Dohi $S$, Naito H. Alteration of double-lumen endobronchial tube position by flexion and extension of the neck. Anesthesiology 1985; 62: 696-7.

5. Fortier $G$, Cote D, Bergeron C, Bussieres JS. New landmarks improve the positioning of the left Broncho-Cath double-lumen tube-comparison with the classic technique. Can J Anesth 2001; 48: 790-4.

6. Lohser J, Brodsky JB. Silbronco double-lumen tube. J Cardiothorac Vasc Anesth 2006; 20: 129-31.

7. Campos JH, Hallam EA, Van Natta T, Kernstine KH. Devices for lung isolation used by anesthesiologists with limited thoracic experience: comparison of double-lumen endotracheal tube, Univent torque control blocker, and Arndt wire-guided endobronchial blocker. Anesthesiology 2006; 104: 261-6, discussion 265A.

8. Benumof JL, Partridge BL, Salvatierra C, Keating J. Margin of safety in positioning modern double-lumen endotracheal tubes. Anesthesiology 1987; 67: 729-38. 
9. Benumof JL, Harwood I, Pendleton S. Major obstruction of the right mainstem bronchus caused by placement of a right axillary roll. J Cardiothorac Vasc Anesth 1993; 7: 200-1.

10. Adnet F, Borron SW, Dumas JL, Lapostolle F, Cupa M, Lapandry $C$. Study of the "sniffing position" by magnetic resonance imaging. Anesthesiology 2001; 94: 83-6.
11. Klein $U$, Karzai $W$, Bloos $F$, et al. Role of fiberoptic bronchoscopy in conjunction with the use of double-lumen tubes for thoracic anesthesia: a prospective study. Anesthesiology 1998; 88: $346-50$. 